\title{
INTERRELIGIOUS ORIENTATIONS AMONG SOUTH AFRICAN YOUTH: EXPRESSIONS OF RELIGIOUS IDENTITY ${ }^{1}$
}

\author{
JACO DREYER \\ University of South Africa \\ HENDRIK PIETERSE \\ University of South Africa \\ JOHANNES A. VAN DER VEN \\ Catholic University of Nijmegen
}

\begin{abstract}
In a religiously plural world it is important to ask how people of different faiths and with different religious identities can live justly and harmoniously together. In this article we take as point of departure that there is an inescapable link between a person's religious identity and his or her attitudes towards adherents of other religious. Against the background of a narrative understanding of religious identity, we explore three questions regarding the interreligious orientations of a sample of South African youth: What are the interreligious orientations of this sample of South African youth? How do they evaluate these interreligious orientations? What is the religious location of these interreligious orientations?
\end{abstract}

Keywords:

Religious identity, narrative identity, exclusivism, inclusivism, pluralism

\section{INTRODUCTION}

In his book On identity Amin Maalouf (2000, p. 9) sets himself the task to try to understand why so many people commit crimes nowadays in the name of religious, ethnic, national or some other kind of identity. Maalouf, being both Algerian and French, Christian and having Arabic as his mother tongue, born from a Protestant father and having a Catholic mother, describes the complexity and paradoxes of identity, the many, often conflicting allegiances that shape our identities, the processes of acquiring a unique, irreplaceable identity, and the conditions for the formation of identities. Of particular importance is that Maalouf singles out religion as one of the major causes of conflict in societies around the world. Despite all the positive aspects that he contributes to religion, in his experience religion causes so much conflict and pain, that he writes (Maalouf, 2000, pp. 80-81): 
I dream not of a world where religion no longer has any place but one where the need for spirituality will no longer be associated with the need to belong. [...] A world in which religion will no longer serve to bind together warring ethnic groups. It is not enough now to separate Church and State: what has to do with religion must be kept apart from what has to do with identity.

Do we have to follow Maalouf in this despairing view of the role of religion regarding identity? Is it possible to separate religion from identity as he suggests in order to avoid conflict?

We have to agree with Maalouf that religious diversity and the problems it creates cannot be ignored today in most parts of the world. Religious diversity is an important part of the pluralism and diversity of our times. The days are gone that the world religions could be related to specific geographical areas on our planet. The massive migrations of people in the twentieth century as well as the communication explosion have led to multifaith societies in many parts of the world. There are no longer oceans separating Christians from adherents of other faiths, and Christians, Muslims, Hindus, Sikhs and Buddhists rub shoulders on every street in Western countries, writes Bosch (1991, p. 475). Despite processes of modernization and rationalization, religion and religious issues still seem to be part of the fabric of modern societies. It is common knowledge that religious conflicts are often in some way intertwined with many of the conflicts all over the world, for example in Northern Ireland and the Middle East. These conflicts are not only between the world religions, but also within religions (such as the Catholic-Protestant antagonism in Northern Ireland). This leads to the view that world peace depends among other things on peace among the various religions (cf. Küng et al., 1993, p. 441). Even in less extreme cases religious diversity has some conflict potential and is often experienced as a problem. There seems to be a renewal of the traditional bond between religion and nationalism in certain societies and an increase in the kind of religious expression associated with fundamentalist and national religious expansion through religious communities catering for racial, ethnic and social identities (To \& Tulasiewicz, 1993, p. 178; cf. Bosch, 1991, p. 476). Even established democracies seem to struggle with this religious plurality as part of multicultural societies, as multiculturalism and religious diversity often go hand in hand. The question thus remains: How can people of different faiths and with different religious identities live justly and harmoniously together in a multireligious, democratic society which is increasingly growing into a 'global village'? (cf. Ziebertz, 1993, p. 89).

One of the problems regarding religious identities in a multireligious 
world is the exclusiveness of religious claims, the view that 'my religion' is in some way unique, exclusive, superior, definitive, normative and absolute, that my religion is something special (cf. Knitter, 1985, p. 18; Bosch, 1991, p. 477). Although religious identity is certainly much more than this, one cannot escape the question of the other, of other religions and faith traditions in a religiously plural world (cf. Roebben, 2000). In affirming one's religious identity, one has to face the question of the diversity of humankind's religious life. This brings us to postulate an inescapable link between a person's religious identity and his or her attitudes towards the adherents of other religions, that is, his or her interreligious orientations.

The aim of this article is to explore the expressions of religious identity of a sample of South African youth by reporting on their interreligious orientations. In section two the notion of religious identity is approached from Ricoeur's idea of narrative identity. In section three we explicate the theoretical framework for our empirical research on interreligious orientations. This is followed by a discussion of the results of empirical research on the interreligious orientations of a section of today's South African youth (section 4). We end with a short conclusion (section 5).

\section{Religious Identity: A Narrative Perspective}

In this section we approach the notion of religious identity from Ricoeur's idea of narrative identity (cf. Dreyer, 2000). The notion of narrative identity has arrived relatively late in Ricoeur's works. It first appears towards the end of his trilogy Time and Narrative (Ricoeur, 1984; 1985; 1988) where he introduced the idea of narrative identity as a way to mediate psychological and cosmological time. However, in his next major publication Oneself as Another (1992) the notion of narrative identity takes center stage. In this section we will not try to reconstruct Ricoeur's use of this term. Our attention will be limited to a short discussion of two important dimensions that we identify in Ricoeur's use of the term, namely a temporal and a relational dimension, and a brief exploration of the notion of religious identity from this perspective of narrative identity.

We start with the temporal dimension. In Oneself as Another, Ricoeur (1992, pp. 115-116) distinguishes two confronting uses of the concept of identity. On the one hand identity is seen as sameness or some permanence in time. He refers to this view as idem-identity from the Latin term idem that means the same or the same one. On the other hand identity is seen as selfhood (Latin ipse) (Ricoeur, 1992, pp. 115-116). Ipse-identity, 
according to Ricoeur (1992, p. 2), implies 'no assertion concerning some unchanging core of the personality' and, in contrast to idem-identity, accommodates change over time (cf. Hughes, 1999, p. 50). This tension between identity as sameness (idem-identity) and identity as selfhood (ipse-identity) plays a central role in Ricoeur's thoughts on personhood and forms the background to his introduction of the term narrative identity. In his typical dialectical style Ricoeur seeks a way to bring these two models of identity into a creative tension. According to Ricoeur the confrontation between idem- and ipse-identity centers around the question of permanence in time. His creative insight in this regard is the distinction between two different forms of permanence in time which he sums up in the expressions character and keeping one's word (Ricoeur, 1992, p. 118). On the basis of these two models of permanence in time he hypothesizes that permanence of character, which is 'the set of lasting dispositions by which a person is recognized' (Ricoeur, 1992, p. 121), expresses an almost complete overlap between identity as sameness and selfhood, while faithfulness to oneself in keeping one's word points to the extreme gap between identity as sameness and selfhood: 'In keeping my word and responding to the call of the other, I manifest a form of permanence in time as an acting and suffering being, a permanence that cannot be reduced to the substratum of character traits' (Hughes, 1999, p. 51). Identity as sameness and selfhood can therefore not be reduced to each other.

From this temporal perspective the distinction between idem-identity (with character as paradigm) and ipse-identity (with keeping of one's word or promise as paradigm) reflects a basic tension regarding identity, namely between stability and change. Although a simplification, one can say that idem-identity, closely related to the notion of character, refers to the relative stability of identity as a product of a certain genetic code, a specific body, acquired habits, values, and identifications. Ipse-identity, on the other hand, refers to the possibility of change, of breaking with the sameness of character. From a temporal perspective, personal identity always reflects this tension between selfsameness (character) and self-constancy (promise). Van den Hengel (1994, p. 467) refers to this as Ricoeur's theory of the internal dialectic of the human self, and explains it as follows:

In the narrative there is an interaction of a self that, on the one hand, maintains an identity of constancy (a self that remains the same, hence 'sameness'), with a self that, on the other hand, projects itself into the future and commits itself to change and transformation (a self that is not yet but becomes in the 'kept word,' which Ricoeur calls 'ipseity'). 
The dialectical relationship between idem- and ipse-identity, between character and keeping one's promises, thus describes a fundamental tension or dialectics implied by the temporal dimension of narrative identity, namely the tension between stability and change, or, in the words of Ricoeur, between sedimentation and innovation.

How can we deal constructively with this tension between stability and change, between identity as self-sameness and identity as self-constancy? It is at this point that Ricoeur (1992, pp. 118-119) introduces narrative theory. He maintains that narrative theory, and in particular the notion emplotment, provides important resources in this regard, if not to unravel the problematic at least in clarifying in what way it is problematic (Ricoeur, 1995, p. 308; cf. Ricoeur, 1996, p. 451). Narrative configuration refers to the dynamic of emplotment. Emplotment of action is important as it provides a synthesis of the multiple events or incidents: 'the plot has the power to make a single story out of the multiple incidents, or, if you like, of transforming the manifold happenings into a story' (Ricoeur, 1986, p. 122). Furthermore, a plot does not only tie multiple events together, but it also unifies widely divergent and even opposing events. It provides a synthesis of the heterogeneous. The result is a single story that 'turns the plot into a unity which one could call both concordant and discordant' (Ricoeur, 1986, p. 123). A plot thus brings some order on events. A story is more than the mere succession of events. Through the act of plotting it gains an outline that is inconceivable without some kind of temporality: 'Narratives, thanks to their emplotment, have a specific temporality that weaves their episodes into a comprehensible whole that cannot be reduced to an atemporal idea' (Pellauer, 1997, p. xv). It is this power of unification of a narrative that helps us to see how it is possible to integrate diversity, variability, discontinuity, and instability with sameness and stability (Ricoeur, 1992, p. 140). Ricoeur (1991b, p. 77) concludes: 'It is primarily in the plot therefore that we must search for the mediation between permanence and change'.

The question now arises: what is the relation between narrative and identity? With reference to Hannah Arendt, Ricoeur (1988, p. 246) maintains that to state the identity of an individual is to answer the question: 'Who did this?' and to answer the question 'Who?' is to tell the story of a life. The unity of a life is the unity of a told story, says Ricoeur (in Reagan, 1996, p. 112). Stories give unity, 'not unity of substance but narrative wholeness' (Ricoeur, 1986, p. 132). Narrative, due to the power of unification, the power to synthesize the heterogenous, to turn multiple events in a 'plot', and to establish a concordance from a discordance as discussed above, thus provides the resources, the 'privileged mediation' (cf. Ricoeur, 
1991a, p. 188), to establish the coherence, the 'identity', of a person.

Personal identity is thus not a given. It is an achievement, a narrative accomplishment. Stated differently, it is in the telling of stories, and in the listening to the other's stories, that a 'life story', an identity, is shaped. This narrative identity is never a finished product. The 'life story' always has to be recounted. To recount is, however, not the same as to repeat or to reproduce. This brings us back to the tension between stability and change, between sedimentation and innovation. The temporal dimension of narrative identity stresses the importance to keep a healthy relationship between stability and change, between sedimentation and innovation.

The second aspect of narrative identity that we would like to highlight is its relational dimension. A narrative identity is not only a temporal identity, it is also a relational identity. Underlying the relational dimension is another important dialectic, namely that of the 'self' and the 'other-thanself'. Ricoeur also relates this tension to the distinction between idem(with character as its paradigm) and ipse-identity (with keeping a promise as paradigm) that we have explained above. The key idea in this case is that personal identity is always constituted in relation to others. This is most apparent in terms of ipse-identity. The keeping of one's word, of holding to your promise, always implies an 'other' towards which the promise is made. Personhood in the sense of ipse-identity implies a responsibility towards others. However, the tension between the 'self' and the 'other-than-self' is not restricted to the pole of ipse-identity. The 'other' is also important in terms of idem-identity. On a biological level, the 'other' is reflected in the genetic code of a person, and on a psychological level the 'other' is always present in terms of our acquired habits, values, and identifications. In the words of Hughes (1999, p. 56):

If we look again at the two models of personal identity, we see that selfhood involves a dialectic of self and other-than-self not only in the internalized values and acquired habits and identifications of one's character, but also in the response to the other and responsibility for the other at the heart of promising.

The tension between the self and the other-than-self is thus implied by the two poles of identity as sameness and identity as selfhood.

How can narrative theory contribute to the mediation of this dialectic of self and the other-than-self? Ricoeur (1992, pp. 146-148) again draws on the notion of emplotment. This time, however, not on the emplotment of action as in the case of the temporal dimension, but on the emplotment of character. Ricoeur refers here to the necessary correlation between plot and character. Telling a story is not only relating the actions, but also 
saying who did what and how. In a narrative we identify the different roles characters play. We get to know the characters as agents and sufferers, as persons taking initiative but also suffering from the abuses of power. But more than this, we also get to know the identity of the characters: 'The narrative constructs the identity of the character, what can be called his or her narrative identity, in constructing that of the story told. It is the identity of the story that makes the identity of the character' (Ricoeur, 1992, pp. 147-148). In the story told we get to know the characters as heros or as villains, as characters loved and respected or not, says Ricoeur. We see how different characters' actions influence and shape each other, we recognize their habits and values, but also the promises made and kept or not kept.

What are the implications of this aspect of narrative theory for personal identity? One can say that the relational dimension is quite apparent in the construction of personal identity. We do not only construct our stories from memory, but also from the stories we are being told. This is most pronounced in the stories regarding my conception, birth and childhood which are not even part of my own memories - they belong to the stories of significant others who tell stories about me - and the stories regarding my death which will belong to those who survive me (cf. Hughes, 1999), but it is also true throughout life. The relational nature of narrative identity is also implied by the fact that our life stories are composed not only on the basis of our own stories, but also on the stories that others tell about us. The stories of our lives are never told in isolation. Personal identity always involves others. Like characters in a narrative we are 'entangled in stories'.

What is the relation between the temporal and the relational dimensions of narrative identity? On the basis of our interpretation of Ricoeur's ideas it seems that the temporal and relational dimensions of narrative identity are intimately related. A major stimulus in the direction of innovation and of changing the dominant 'story' of a person, which is a key issue in the temporal dimension, comes from the relational dimension of narrative identity. Innovation requires a rereading and reappraisal of a 'life story', especially with a view to past promises which have not been kept. The dialectic of stability and change of the temporal dimension is thus connected to the dialectics of the self and the other-than-self of the relational dimension. Among other things, it implies that recounting of the narratives of collectivities must be done from a relational perspective.

What is a 'religious identity' from the perspective of narrative identity presented above? From the perspective of narrative identity, religious identities share the basic tension between idem- and ipse-identity. The tem- 
poral dimension of religious identity is expressed in the never-ending tension between stability and change, sedimentation (tradition) and innovation. There is no final 'religious story', no master 'religious plot' to express a person's religious identity. Religious identity is not something static, and has to be recounted continuously. An important aspect of the 'religious story' is the story or stories that we are being told, the religious tradition(s) in which we are socialized. This provides an element of stability. However, from the perspective of narrative identity we have to face the tension between sedimentation (tradition) and innovation. If not, tradition tends to become an ideology. The notion of discordant concordance to which we have referred above helps us to understand how religious diversity, variability, discontinuity and instability can be integrated. It helps us to understand how it is possible to make some kind of synthesis, to recover (rather than impose from without) a plot from the many religious stories in which we are entangled. From this perspective we gain insight into the struggle to compose a 'religious story' from the diverse actions and events that characterize a person's life, the outcome of which can at best be regarded as an unstable equilibrium.

From the relational perspective of narrative identity, a religious identity cannot escape the tension between self and other (cf. Hermans, 2001). The key idea in this case is that religious identity is always constituted in relation to others. Narrative identity stresses that the 'other' is always present in terms of our acquired habits, values, and identifications. Regarding religious identity one can refer here to the role of religious socialization. Religious identity from a narrative perspective stresses that religious themes, roles, and stories that form part of our 'life stories' do not come from nowhere. For example, religious socialization often plays a very important role regarding the religion, faith tradition or church to which a person belongs, or does nót belong, his/her religious practices, and attitudes towards people of other beliefs or faith traditions. From this idemidentity our religious identities always reflect the other-than-self. Religious identity from a narrative perspective also stresses the tension between self and other in terms of ipse-identity. As we said above, the keeping of one's word, of holding to your promise, always implies an 'other' towards which the promise is made. Religious identity in the sense of ipse-identity implies a responsibility towards the other, especially the suffering other (cf. Hermans, 2001, pp. 306-307), whether or not they belong to the same religion, faith tradition or church as we do. The challenge implied by the relational dimension of religious identity is to mediate the tension between the self and the other-than-self in the continuous process of reconstructing religious identity, and to recognize the inherent ethical nature of religious identity. 


\section{INTERRELIGIOUS ORIENTATIONS}

In this part of the paper we turn our attention to the theorization of interreligious orientations. What models of interreligiosity can we distinguish? One of the most 'popular' typologies of the relation between Christianity and other religions is proposed by Race (1983), who distinguishes three main models of interreligiosity, namely exclusivism, inclusivism and pluralism. According to Race $(1983$, p. 7) these models give a broad typological framework within which most current Christian theologies of religions can be placed. The essence of exclusivism is that salvation is only possible through Jesus Christ (cf. Acts 4:12; John 14:6), and revelation in Christ is the sole criterion by which the relationship between Christianity and other faiths can be understood and evaluated (cf. Race, 1983, pp. 10-11). Race (1983, p. 24) says that this model is the most clearcut, because it involves no complicated theory of religious experience; it appeals to 'what for many is a self-evident biblical witness', it is logical and it corresponds most closely to the orthodox Christian view through the centuries. The model of inclusivism, with its roots in the early Christian tradition, implies both an acceptance and a rejection of other faiths, a dialectical 'yes' and 'no' (Race, 1983, p. 38). Although this approach accepts that the grace of God is also at work in the other religions, it maintains the uniqueness of Christ and the superiority of Christianity. Within this view, the Christian religion is regarded as 'the seed' for other religions. Two equally binding convictions have to be kept in balance, the universal will of God to save, and the uniqueness of the revelation in Christ (Race, 1983, p. 54). Although different strands of the inclusivistic approach can be distinguished (cf. Race, 1983, pp. 68-69), it is usually associated with the Roman Catholic Karl Rahner's theory of 'anonymous Christianity' (cf. Race, 1983, pp. 43-50; Hick, 1985, pp. 33-34). In comparison with the models of exclusivism and inclusivism which can both claim 'ample pedigree in the Christian tradition' (Race, 1983, p. 70), the model of pluralism belongs to the modern period. This model stresses that the knowledge of God is partial in all faiths, including Christianity, and that religious truth cannot escape cultural relatedness (cf. Race, 1983, pp. 72, 76; Netland, 1986, p. 22). According to Race (1983, p. 77) the pluralist position seems to give the simplest solution to the problem of religious diversity.

Although there seems to be much consensus regarding the models of exclusivism and inclusivism, the third model in Race's typology, pluralism, is problematic. Knitter (1995, p. 23) laments the often stereotyped image of the pluralist model and stresses that a 'plurality of pluralists' exists. It is thus better to speak of different versions of a pluralistic the- 
ology of religions. We distinguish here only the relativistic and dialogic versions of pluralism.

The core idea of relativistic pluralism is that the various religions are in principle equal. All religions are merely branches of the same tree. From a phenomenologicalperspective this implies that God's salvific work takes different forms in different cultures and historical periods. These cultural differences, however, are not substantial and of little importance because behind them is the one God (Ziebertz, 1993, p. 90; 1994, pp. 153, 157). From a psychological perspective the equality of religions is linked to the common divine soul present in the 'collective subconscious' (in Jung's terms) of humankind. Although myths and symbols differ according to culture, the core of this archetype remains identical (Ziebertz, 1993, pp. 90-91; 1994, pp. 153-154, 157). All religions give expression to the human being's emotional search for happiness and joy (Van der Ven, 1994, p. 250). One of the weaknesses of this model is that it runs the risk of reductionism in which the religious dimension is reduced to the philosophical (phenomenological) or psychological equality referred to above. In this way the intrinsic value of religion, namely as human engagement with transcendence, is lost. Another potential problem of religious relativism is that it can end in religious indifferentism (Van der Ven, 1994, p. 250).

The relativistic version of pluralism has led authors such as Knitter (1995; 1996), Küng (Küng et al., 1993), and Tracy (1990) each in his own way to stress the importance of interreligious dialogue within a pluralistic approach which takes otherness and difference between religions seriously. Instead of accepting a pluralistic theology of religions in which the 'the real diversity among religions becomes submerged in a placid sea of sameness' (Knitter, 1995, p. 31), this 'dialogic approach' opts for a critical correlational dialogue in which all sides are able to hear and at the same time to speak to and challenge in return (Knitter, 1995, p. 24; cf. Küng et al., 1993, p. xix; Tracy, 1990). An important element of this approach is that there should be dialogue or communication between one's own and other religions. This dialogue, however, should not be conducted from an 'I' perspective only, in which one's own religion is taken as the most valuable way to salvation or religious truth such as the exclusivistic and inclusivistic models imply. Nor should this dialogue be conducted only from a neutral 'it' perspective, in which personal involvement with religious matters is avoided, such as in the relativistic model. The core of this model is that the dialogue between religions should be characterized by a perspective exchange. This presupposes not only an established religious identity and personal engagement with religious matters in a specific religious tradition, but also the ability and the willingness to interpret other 
religions from their own perspectives. Such a perspective exchange thus implies a double, reciprocal auto- and allo-interpretation of one's own and the other religion (cf. Waldenfels, 1990, pp. 18-21). This model, which is based on the principle of dialogue, reflects a relational notion of the truth and can be regarded as a modern theological orientation to the problem of religious diversity (cf. Ziebertz, 1993, pp. 91-92). It also implies a striving for mutual understanding, tolerance and respect as well as self-reflexivity and self-criticism. Van der Ven (1994, p. 253) states that this model is based on humanistic values such as the right to conscience, the right of religious freedom (between and within religions), and the intrinsic worth of the individual human being.

For the research on interreligious orientations among South African youth we distinguished four interreligious orientations based on these theological models on the meeting between religions in order to try to establish their interreligious orientations. The four orientations were operationalised by four items each, which resulted in a set of 16 questions. ${ }^{2}$ We operationalised the monoreligious (exclusivistic) orientation in our research with items such as 'Only in my religion can people receive true salvation' and 'My religion contains the one, true light of redemption'. The monoreligious (inclusivistic) orientation was operationalised in items such as 'Compared with my religion, the other religions contain only part of the truth' and 'Compared to the other religions, my religion contains the supreme salvation'. Examples of our conceptualization of the multireligious orientation are items such as 'All religions are equally valuable, they form different ways to the same salvation' (the phenomenological perspective) and 'There is no difference between religions; they all stem from a longing for God' (the psychological perspective). Lastly, the interreligious dialogue orientation was operationalised in items such as 'The way to real salvation is only to be found in dialogue between the religions' and 'Before finding authentic (real) redemption religions must enter into dialogue with each other'.

\section{Interreligious Orientations and Their Religious Location of a Sample of South African Youth}

In this section of the paper we attend to three questions. What are the interreligious orientations of South African youth? How do they evaluate these interreligious orientations? What is the religious location of these interreligious orientations? To investigate the interreligious orientations among South African youth we included the questions on 'interreligious 
orientations' in a survey we conducted in 1995/96 among 538 Grade 11 students from Anglican and Catholic church-affiliated schools in the Johannesburg/Pretoria region. ${ }^{3}$ This was followed by a survey which we conducted in 1996 among 917 Grade 11 students who attend public schools also in the Johannesburg/Pretoria region. ${ }^{4}$ These students had to fill in a questionnaire that was especially designed for this purpose.

What are the interreligious orientations of this sample of South African youth? This question can be formulated in a more specific way. Do the orientations of South African youth reveal the same structure as the conceptual structure (see Figure 1) suggests? In other words, are their orientations towards other religions divided into the four orientations we have distinguished in the previous section?

To answer this question we conducted an overall factor analysis on the answers given by these Standard 9 (Grade 11) students. For statistical reasons, two items had to be eliminated. ${ }^{5}$ Four factors were extracted from the students' responses to the remaining items. As Figure 1 shows, only the multireligious orientation receives empirical support. ${ }^{6}$ The distinction between monoreligious (exclusivistic) and monoreligious (inclusivistic) orientations, however, does not seem to apply in the empirical domain. These respondents do not distinguish between exclusivistic and inclusivistic orientations. Empirically, these variants are not distinct but form one factor. Underlying both the exclusivistic and inclusivistic orientations is the absolutistic claim that my religion is the only true religion (cf. Sterkens, Hermans \& Van der Ven, 1997, p. 11). We therefore eliminated the labels exclusivistic and inclusivistic and labeled this factor the monoreligious orientation.

Figure 1: Interreligious orientations

Interreligious orientations

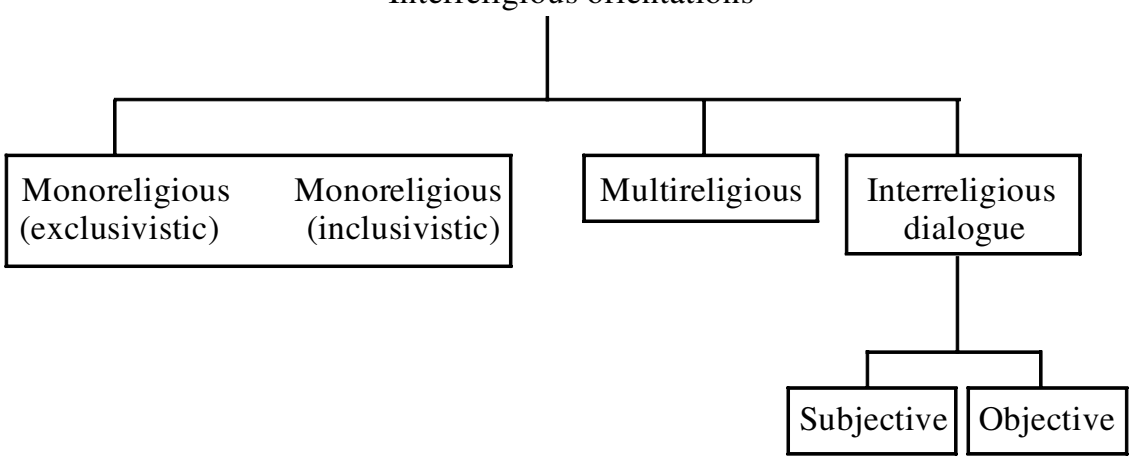


Contrary to our expectations, we found that the interreligious dialogue orientation does not form one factor, but two. This indicates that two empirically distinct dimensions regarding the interreligious dialogue orientation as we conceptualized it can be distinguished. On close inspection of the two factors it became clear that two underlying dimensions are indeed present in our operationalisation of the dialogic orientation. The first refers to dialogue from a personal, subjective perspective, while the second factor seems to stress dialogue from a more objective and impersonal perspective. Although the respondents most probably are not aware of the theologies of salvation and differences in 'salvation language', the different words used in the items of the two factors, respectively salvation and redemption, strengthen the above interpretation of a distinction between subjective and objective dialogic orientations. According to Rahner and Vorgrimler (1983, p. 458) the term salvation "does not primarily signify an "objective" achievement ... but rather a "subjective", existential healing and fulfilment of life'. It is not only salvation in a general objective sense that is at stake in the interreligious dialogue, but $m y$ salvation. ${ }^{7}$ In contrast, the term redemption ${ }^{8}$ in the Christian sense refers to an 'objective' event. The subjective-objective distinction also makes sense regarding the wording of the other two items, ${ }^{9}$ namely 'God' and 'real truth' as the object of the dialogue between the religions. The aim of the interreligious dialogue can be seen as the search for real truth, which has the connotations of objectivity, universality and impersonality, in contrast to the search for God which refers to a much more personal and subjective event. These factors were therefore labeled interreligious dialogue (subjective) orientation and interreligious dialogue (objective) orientation respectively.

The question now arises whether differences exist in the valuations of these interreligious orientations. In other words, is there a specific interreligious orientation that these youngsters value more highly than the other? Table 1 shows the average scores on the different interreligious orientations on a five-point scale ( $1=$ I totally disagree, $5=$ I fully agree). While dealing with two different subpopulations, namely students of private and public schools, we also look at the differences between these two groups. In the first column you can find the averages for the students of the private schools. The second column contains the average scores for the students of public schools, the third column shows the results of the two sample surveys together and finally we present the $\eta$.

There are no great differences between students of public and private schools concerning the interreligious dialogue orientations, both subjective and objective. The respondents in our population are negatively ambiva- 


\section{Table 1: Interreligious orientations}

\begin{tabular}{lcccc}
\hline \multicolumn{1}{c}{ Average } & & & & \\
& Priv. & Pub. & All & $\eta$ \\
\hline Monoreligious & 2.5 & 3.1 & 2.9 & $.31^{*}$ \\
Interreligious dialogue (subjective) & 2.7 & 2.6 & 2.6 & $.07^{*}$ \\
Interreligious dialogue (objective) & 3.3 & 3.1 & 3.2 & $.06^{*}$ \\
Multireligious & 3.8 & 3.3 & 3.5 & $.23^{*}$ \\
\hline
\end{tabular}

* There is a significant difference in mean scores between students of private and public schools (p. 0.05). The height of the $\eta$ is an indication of the relevance of the difference.

lent ${ }^{10}$ about an interreligious dialogue orientation from a subjective perspective, and positively ambivalent about an interreligious dialogue orientation from an objective perspective. Regarding the two interreligious dialogue orientations that we have distinguished above, they clearly favor an objective orientation. This means that they prefer dialogue between religions to be conducted from an objective, distant perspective rather than from a subjective and personal faith perspective.

The mean scores on the monoreligious and multireligious orientations differ significantly between students of private and public schools. The respondents of the private schools are negatively ambivalent about a monoreligious orientation, and those of the public schools positively ambivalent. The difference in average between these two groups is significant. Respondents from the public schools score on average more than half a scale point higher on a monoreligious orientation than students of the private schools. Amongst the pupils of the private schools, this orientation which claims uniqueness and/or superiority for one's own religion in the meeting between religions, received the lowest average score from our respondents.

The highest average scores for both groups and for the groups together are obtained for the multireligious orientation. As a group these students are positive towards such an orientation in the meeting between different faiths, that is, they favor an orientation which regards all faiths as equal, which values the common core of all religions more than the cultural particulars of the different religions, and which relativizes the special truth of a specific religion (cf. Ziebertz, 1993, pp. 93, 96). Again the difference in average between the two groups is significant. Respondents from the private schools score on average half a scale point higher on this orientation than students of the public schools. 
The answer to the above question, namely whether there is a specific interreligious orientation that these youngsters value more highly than the other, is that these students clearly favor the multireligious orientation. Why do they favor a multireligious orientation? We suggest two possibilities. First, it may be a youth phenomenon. Ziebertz (1993, p. 97), with reference to Nipkow's work (cf. Nipkow, 1994, p. 224), maintains that a multireligious attitude regarding the plurality of religions is widely popular among students. Second, this result may be expected, given recent socio-political changes in South Africa, with the concomitant establishment of a secular state, the stress on religious freedom, tolerance and a democratic ethos from political and religious leaders, and the call to transcend cultural and other differences with slogans such as 'One country, one nation' and 'We are one'. The difference in averages between students of public and private schools makes sense if one considers the 'democratic ethos' of the private schools that our respondents attend. Although these schools are private church schools, they are not exclusively for people from these denominations. ${ }^{11}$ Furthermore, not only students who identify with a Christian church or denomination attend these schools, but also students who prefer other, non-Christian religions or no religion at all. These schools have a history of actively striving for tolerance and respect for cultural and religious differences, and were racially integrated even in the heydays of apartheid. ${ }^{12}$

How do we evaluate these research results from the perspective of religious identity? In the previous section we said that religious identity from a narrative perspective is most adequately expressed in terms of the interreligious dialogue orientation. Interestingly these students seem to be positively ambivalent towards religious dialogue on condition that it is conducted from a more distant, objective stance. As a group, they are however negatively ambivalent towards religious dialogue from a more subjective, personal perspective. It is significant that these students, as a group, favor a multireligious orientation. In terms of our discussion above, this can be interpreted as an openness to explore, to recount their identities, to innovate (temporal dimension) and to take the other seriously (relational dimension). It is also interesting to note the differences between students from the public and the private schools. The students from the private schools as a group seem to be closer to the ideal of religious identity that we have set out above. The monoreligious orientation gets the least support from this group, and they score on average higher on the two interreligious dialogue orientations. They also score as a group significantly higher on a multireligious orientation than their peers in the public schools. Whether 
this orientation will in the long run turn out to be so positive is not so easy to answer.

This brings us to the third question: What is the religious location of these interreligious orientations? In this paper we are specifically interested in the question whether particular religious characteristics correlate with these attitudes, and to what extent. In other words: which orientations are found among the religiously and ecclesially committed students?

In order to be able to answer these questions we conducted correlational analyses for a number of religious characteristics to see if these religious characteristics statistically correlate with the students' interreligious orientations in a linear way (rho). The religious characteristics are divided in three groups (cf. Table 2). First, religious socialization (a), which consists of religious communication with parents (compar), transfer of religious values by the parents (transpar), and current religious steering by the parents (steering). Second, the importance that a person attaches to religion, that is, religious saliency (b). The third group of religious characteristics refer to aspects of religious praxis (c), namely praying and bible reading, participation in church activities, and participation in rites of passage. The significant rho's from the correlation analyses appear in Table $2 .{ }^{13}$

Table 2: Religious characteristics of interreligious orientations from correlation analyses (rho)

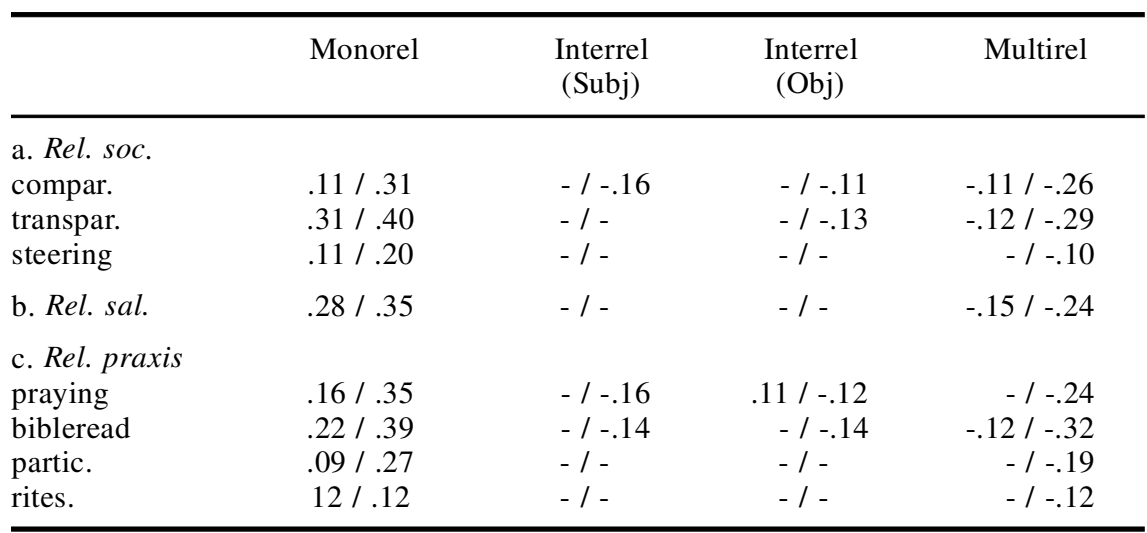

[Abbreviations religious characteristics. Rel. soc. $=$ religious socialization; compar. $=$ reli gious communication with parents; transpar. $=$ religious transfer by parents; steering $=$ religious steering by parents; Rel. sal. $=$ religious saliency; Rel. praxis $=$ religious praxis; bibleread $=$ bible reading; partic. $=$ regular church participation; rites $=$ participation in the rites of passage.

Abbreviations interreligious orientations: Monorel $=$ monoreligious orientation; Interrel $($ Subj $)=$ interreligious dialogue $($ subjective $)$ orientation; Interrel $(\mathrm{Obj})=$ interreligious dialogue (objective) orientation; Multirel = multireligious orientation.] 
We have again treated the two subpopulations, namely the students from the private and public schools, separately. ${ }^{14}$

If we interpret the results of Table 2 in a general way, we see a very clear pattern. All the religious characteristics have a statistically significant, positive correlation with a monoreligious orientation. This means that the more intense their religious socialization (religious communication with, steering and transfer by the parents), the more important they consider religion to be (religious saliency), and the more they are involved in religious practices such as bible reading, praying, participation in churches, the more they are in favor of a monoreligious orientation. Religious socialization and participation in traditional religious practices thus contribute to an attitude that takes one's own religion as the only way to salvation or at least superior to the other religions. It is also interesting to note that the correlation coefficients for the students of the public schools are almost throughout much higher than for those students of the private schools. This implies that religious socialization and participation in religious practices have a greater impact on the choice of a monoreligious orientation for those students who attend public schools.

A second observation is that the religious characteristics in Table 2 correlate negatively with a multireligious orientation. In the case of students from public schools, religious socialization and participation in religious practices correlate throughout negatively with a multireligious orientation. This means that the more intense their religious socialization (religious communication with, steering and transfer by the parents), the more important they consider religion to be (religious saliency), and the more they are involved in religious practices such as bible reading, praying, participation in church activities, the less they tend to favor of a multireligious orientation. This is partly true for the students of the private schools as well, although in the case of this group the correlations are much lower and only one of the four indicators of participation in traditional religious practices, namely bible reading, has a small negative correlation with a multireligious orientation.

The relations between these religious characteristics and the two interreligious dialogue models (subjective and objective) are less pronounced. In the case of students from private schools, religious socialization and participation in religious practices seem to be unrelated to these two interreligious dialogue orientations. The only exception is one small positive correlation between how often they pray and an objective interreligious dialogue orientation. In the case of students from the public schools we see a number of small, but negative correlations with these two inter- 
religious dialogue orientations. This means that the more they communicate with their parents on religious matters, and the more the read the bible and pray, the less they are inclined to favor these interreligious dialogue orientations.

What can we learn from these results regarding the religious identities of these students? The positive correlations between religious socialization and a monoreligious orientation imply that religious socialization as experienced by these young people contribute to a view that their own religion is the only truth or at least superior to other religions. Religious socialization therefore tends to foster a religious identity in which the tension between stability and change is decided in favor of stability, and the tension of self and other is decided in favor of the self. Religious socialization for these students thus seems to prevent rather than encourage the establishment of a narrative religious identity. Furthermore, the absence of positive correlations between the interreligious dialogue models (both subjective and objective) also indicates that religious socialization does not contribute to the formation of narrative religious identities among these students. It is interesting to note that despite all the negative correlations between religious socialization and a multireligious orientation, this orientation was valued higher on average than all the other orientations for these students. One can say that these students are willing to explore religious matters despite their religious upbringing and socialization.

\section{CONCLUSION}

We have to agree with Maalouf (2000) that religious identities are indeed problematic in multicultural, multireligious societies. We have to agree with him that identities can kill, that 'identity' can be a false friend in this complex world in which we live, that we have to tame the 'wild beast of identity' (Maalouf, 2000, p. 128). Should we, as religious educators, not follow Maalouf in trying to keep religion apart from that what has to do with religion? We do not think so. On the basis of Ricoeur's notion of narrative identity we can construct a view of religious identity that could be positive. A major challenge for religious educators, however, is to contribute to the formation of religious identities that do not let go of the tension between sedimentation and innovation, between the self and the other-than-self. Perhaps we can be inspired towards this task by our narrative and ethical imaginations, by dreaming with Maalouf (2000, p. 132) when he writes: 
I can't help dreaming of the day when the region where I was born will follow the path I have described, leaving behind the era of tribes, of holy wars and of identities that kill, in order to build something in common. I dream of the day when I can call all the Middle East my homeland, as I now do Lebanon and France and Europe; the day when I can call all its sons, Muslim, Jewish and Christian, of all denominations and all origins, my compatriots. In my own mind, which is always speculating and trying to anticipate the future, it has already come to pass. But I want it to happen one day on the solid ground of reality, and for everyone.

\section{NOTES}

1. This article is a revised version of a paper read by the first author at the Education and Ethos Network Conference on 1 February 2001 at the University of Nijmegen, the Netherlands.

2. Available from the first author.

3. This sample displays the following demographic characteristics: $49 \%$ are boys, $51 \%$ girls; $67 \%$ have English, 3\% Afrikaans, 24\% one of the nine other official languages, and 6\% any other language as their home language; the highest educational level of $26 \%$ of fathers and $34 \%$ of mothers falls in the category grade 3 through grade $12 ; 48 \%$ of fathers and $54 \%$ of mothers have had some form of continuing education after grade 12 , while $27 \%$ of fathers and $12 \%$ of mothers have a master's or doctoral degrees; $34 \%$ support the ANC, $25 \%$ the Democratic Party, 29\% the National Party and 12\% support other parties; 31\% are Catholic, 26\% Anglican, 8\% Methodist, 23\% belong to some other Christian denomination, $8 \%$ have a different religion and $4 \%$ have no religion at all.

4. This sample shows the following demographic characteristics: $51 \%$ are boys, $49 \%$ girls; $32 \%$ have English as their home language, $41 \%$ Afrikaans, $22 \%$ one of the nine other official languages and 5\% any other language; the highest educational level of $40 \%$ of fathers and $51 \%$ of mothers falls in the category grade 3 through grade $12,47 \%$ of fathers and $43 \%$ of mothers have had some form of continuing education after grade 12, while $13 \%$ of fathers and $6 \%$ of mothers have a master's or doctoral degrees; 24\% support the ANC, 9\% the Democratic Party, $38 \%$ the National Party and 29\% support other parties; $12 \%$ are Catholic, $7 \%$ Anglican, $11 \%$ Methodist, $29 \%$ belong to the Afrikaans-speaking Reformed Churches, 34\% belong to some other Christian denomination, 3\% have a different religion and $4 \%$ have no religion at all.

5. For the statistical conventions we followed in the factor analyses we conducted for this article, see Van der Ven (1993). The factor analysis output used in this article is available from the authors.

6. The empirical domain is indicated by text boxes.

7. The item reads: 'The way to real salvation is only to be found in dialogue between the religions.'

8. The item reads: 'Before finding authentic (real) redemption religions must enter into dialogue with each other.'

9. The items are: 'God is only found in the meeting between religions' and 'The real truth can only be discovered in the communication between the religions'

10. We interpret the averages as follows: 1.00-1.80 very negative, 1.81-2.40 negative, 2.413.00 negatively ambivalent, 3.01-3.40 positively ambivalent, 3.41-4.20 positive, and 4.21-5.00 very positive.

11. Although we have not studied the religious education policies of these schools, we suspect that they adopted a multireligious rather than a confessional approach to religious education.

12. The different histories and the 'democratic ethos' of these Anglican and Catholic private 
schools clearly separate them from the public schools. This sample can therefore not be taken as representative of South African youth in general.

13. For the statistical conventions see Van der Ven (1993), parts IV and V. The statistical output is available from the authors.

14. In Table 2 the statistical results for the students from the private schools are presented to the left of the "/" and those of the public schools on the right.

\section{REFERENCES}

Bosch, D.J. (1991). Transforming Mission: Paradigm Shifts in Theology of Mission. Maryknoll, New York: Orbis.

Dreyer, J.S. (2000). The Lens of Collective Narrative Identity: Ecclesiological Explorations from South Africa. Practical Theology in South Africa, 15(2), 21-52.

Hermans, C.A.M. (2001). The Other in Dialogue: Interreligious Communication from a SocioCultural Perspective. In H.-G. Ziebertz, F. Schweitzer, H. Häring \& D. Browning (Eds.), The Human Image of God (pp. 285-309). Leiden: Brill.

Hick, J. (1985). Problems of Religious Pluralism. Hampshire: Macmillan.

Hughes, C.L. (1999). Reconstructing the Subject of Human Rights. Philosophy \& Social Criticism, 25(2), 47-60.

Knitter, P.F. (1985). No Other Name? A Critical Survey of Christian Attitudes toward the World Religions. London: SCM.

— (1995). One Earth, Many Religions: Multifaith Dialogue and Global Responsibility . Maryknoll: Orbis.

- (1996). Jesus and the Other Names: Christian Mission and Global Responsibility. Maryknoll: Orbis.

Küng, H., Van Ess, J., Von Stietencron, H. \& Bechert, H. (1993). Christianity and World Religions. Paths of Dialogue with Islam, Hinduism, and Buddhism. Maryknoll, New York: Orbis.

Maalouf, A. (2000). On Identity. London: Harvill. [Tr. from French by Barbara Bray.]

Netland, H. (1986). The Challenge of Religious Pluralism. TSF Bulletin, 10, 20B25.

Nipkow, K.E. (1994). Ziele Interreligiösen Lernens als mehrdimensionales Problem. In J.A. van der Ven \& H.-G. Ziebertz (Eds.), Religiöser Pluralismus und Interreligiöses Lernen. Kampen/Weinheim: Kok/Deutscher Studien Verlag. [Theologie en Empirie 20.]

Pellauer, D. (1997). Foreword: Recounting Narrative. In M. Joy (Ed.), Paul Ricoeur and Narrative: Context and Contestation. Calgary: University of Calgary Press.

Race, A. (1983). Christians and Religious Pluralism: Patterns in the Christian Theology of Religions. London: SCM.

Rahner, K. \& Vorgrimler, H. (1983). Concise Theological Dictionary. London: Burns \& Oates. Reagan, C.E. (1996). Paul Ricoeur: His Life and His Work. Chicago: University of Chicago Press. Ricoeur, P. (1984). Time and Narrative I. Chicago: University of Chicago Press. [Tr. by K. McLaughlin \& D. Pellauer.]

- (1985). Time and Narrative II. Chicago: University of Chicago Press. [Tr. by K. McLaughlin \& D. Pellauer.]

— (1986). Life: A Story in Search of a Narrator. In M.C. Doeser \& J.N. Kraay (Eds.), Facts and Values: Philosophical Reflections from Western and Non-Western Perspectives (121-132). Dordrecht: Martinus Nijhoff.

_ (1988). Time and Narrative III. Chicago: University of Chicago Press. [Tr. by K. Blamey \& D. Pellauer.]

(1991a). Narrative Identity. In D. Wood (Ed.), On Paul Ricoeur: Narrative and Interpretation (188-199). London: Routledge. [Tr. by D. Wood.]

— (1991b). Narrative Identity. Philosophy Today, 35(1/4), 73-81. [Tr. by M.S. Muldoon.]

_ (1992). Oneself as Another. Chicago: University of Chicago Press. [Tr. by K. Blamey.] 
(1995). Figuring the Sacred: Religion, Narrative and Imagination, Minneapolis: Fortress. [Tr. by D. Pellauer and ed. by M.I. Wallace.]

- (1996). From Metaphysics to Moral Philosophy. Philosophy Today, 40(4/4), 443-458.

Roebben, B. (Ed.) (2000). Religieus opvoeden in een multiculturele samenleving. Leuven: Davidsfonds.

Sterkens, C., Hermans, C.A.M. \& Van der Ven, J.A. (1997). Interreligieus leren op de basisschool. Nijmegen: Nijmeegs Instituut voor Studies in de Empirische Theologie. [Verslag SVOBproject 92085.]

Tracy, D. (1990). Dialogue with the Other: The Inter-Religious Dialogue. Louvain: Peeters.

To, C.-Y. \& Tulasiewicz, W. (1993). Conclusion. In W. Tulasiewicz \& C.-Y. To (Eds.), World Religions and Educational Practice. New York: Cassell.

Van den Hengel, J. (1994). Paul Ricoeur's Oneself as Another and Practical Theology. Theological Studies, 55, 458-480.

Van der Ven, J.A. (1993). Practical Theology: An Empirical Approach. Kampen: Kok Pharos. (1994). Religious Values in the Interreligious Dialogue. Religion \& Theology, 1(3), $244 \mathrm{~B} 260$. Waldenfels, H. (1990). Begegnung der Religionen. Bonn: Borengässer.

Ziebertz, H.-G. (1993). Religious Pluralism and Religious Education. Journal of Empirical Theology, 6(2), 82B99.

- (1994). Religionspädagogik als empirische Wissenschaft: Beiträge zu Theorie und Forschungspraxis. Weinheim: Deutscher Studien Verlag.

Address for correspondence:

Jaco Dreyer

University of South Africa

PO Box 392

Pretoria

0003 South Africa

E-mail: dreyejs@mweb.co.za 